\title{
Effect of ensiled tomato pomace on performance and antioxidant status in the peripartum dairy cow
}

\author{
H. Tuoxunjiang ${ }^{1}$, A. Yimamu ${ }^{1,3}$, X.Q. Li ${ }^{1}$, R. Maimaiti ${ }^{1}$ and Y.L. Wang ${ }^{2}$ \\ ${ }^{1}$ Xinjiang Agricultural University, Collage of Grassland and Environmental Science, Urumqi, 830052, China \\ ${ }^{2}$ Xinjiang Tianshan Animal Husbundry Bio-engineering Co. LTD, Changji 831100, China
}

KEY WORDS: tomato pomace, milk composition, feed intake, nutrient digestibility, antioxidant status, immunity

Received: 13 February 2020

Revised: $\quad 16$ April 2020

Accepted: 15 June 2020
${ }^{3}$ Corresponding author:

e-mail: abibula@sina.com

\begin{abstract}
The aim of this study was to evaluate the effects of partial replacing whole crop maize silage with ensiled tomato pomace (ETP) on feed intake, digestibility, milk yield and composition, antioxidant status and immune response in dairy cows. Fifty pregnant Holstein dairy cows were randomly assigned to 2 groups of 25 cows each, according to calving dates and body weights (BW). Animals from control group were fed total mixed ration (TMR) diet containing whole crop maize silage, while the experimental group was fed TMR diet with 10\% replacement of crop maize silage with ETP silage (dry base). The measurements of blood biochemical and antioxidant, and immunity indices were carried out before calving, at calving, 7 and 14 days after it. Also 14 days after calving feed intake, digestibility, milk yield and composition were examined. It was shown that dry matter (DM) intake and digestibility increased when $10 \%$ of dietary maize silage was replaced with ETP. In animals fed experimental diet milk yield and composition were not altered, but the concentration of vitamins in milk significantly increased. Adding ETP to the diet numerically increased concentrations of total cholesterol, high-density lipoprotein cholesterol, and serum glutamic oxaloacetic transaminase. Improved antioxidant status and increased immunoglobulins A, G, M ( $\lg A, \lg G, \lg M)$ before parturition were observed in experimental animals. So, it is suggested that dietary $10 \%$ replacement of maize silage with ETP had positive effect on milk vitamin contents, antioxidant and immune functions in the early lactating dairy cows.
\end{abstract}

\section{Introduction}

Xinjiang is the largest tomato production and processing area in China, the annual output of processed tomato products is 794468 tonnes (Xinjiang Statistical Yearbook, 2017). Fondevila et al. (1994) and Mdel et al. (2006) observed that tomato pomace contains high amounts of crude protein, ether extract and non-fibre carbohydrate (NFC). In addition, it is also a good source of lycopene, carotene, vitamin E (VE), vitamin C (VC) and nucleosides (Abdollahzadeh and Pirmohammadi,
2010; Fuentes et al., 2013; Rahbarpur et al., 2013; Albanese et al., 2014), which are mainly responsible for tomato's antioxidant capacity (Chew, 1993). Several trace minerals and vitamins are involved in the antioxidant defence system and the deficiency of any of these nutrients may depress immunity of dairy cows during perinatal period (Spears, 2000). Vitamin E seems to be very important in determining health and the immunoresponsiveness of dairy cows (Hogan et al., 1990). Similarly, $\beta$-carotene can affect immune responses and function as an antioxidant (Chew and Park, 2004). So et al. (2019) reported 
that in ruminants fed diets containing tomato pomace nutrients intake and apparent digestibility, dry matter (DM), organic matter, and crude protein indices were increased. Omar and Abdel-Magid (2015) reported that the dried tomato pomace can be substituted in the diets fed to sheep up to $15 \%$ without any adverse effect on the growth performance. Weiss et al. (1997) observed that milk production and composition, dry matter intake (DMI), and nutrient digestibility were not alter by feeding dairy cows wet tomato pomace $(12 \%$ of DM) mixed with wet maize silage. Diets containing lycopene (e.g., tomatoes rich in lycopene) can improve the nutritive value of animal products and so human health (Rozbicka et al., 2012; Czauderna et al., 2020). Ebeid et al. (2015) observed that milk yield and milk compounds were not alter by feeding tomato pomace but the $7 \%$ fat-corrected milk yield and milk fat percentage were increased.

Jin et al. (2014) suggested that diet supplementation with $220 \mathrm{IU}$ of vitamin (VA) per $\mathrm{kg}$ of body weight (BW) may enhance antioxidant and immune functions in dairy cows. In other studies it was suggested that adding $2.431 \mathrm{IU}$ of $\mathrm{VE} / \mathrm{kg} \mathrm{BW}$ of dairy cows during the transition period could improve the performance, immunity and reproductive functions (Weiss et al., 1997). Mainly, during the first weeks of lactation, cows experience immunosuppression and have a high susceptibility to infectious diseases, especially mastitis and metabolic disorders (Goff, 2006; Sundrum, 2015).

However, only a few researches have reported so far the effect of using tomato pomace silage on a milk yield and composition and the immunity function in early lactation dairy cows. The objective of this study was to determine the effect of $10 \%$ ensiled tomato pomace (ETP) incorporated in total mixed ration (TMR) on the feed intake and digestibility of nutrients, milk yield and its composition, antioxidant status and immunity in early lactation dairy cows.

\section{Material and methods}

\section{Tomato pomace silage preparation}

Raw tomato pomace was collected from Tunhe Zhongliang Tomato Products Co., Ltd factories in Chang Ji, Xinjiang (China) and ensiled with $0.002 \%$ Lactobacillus plantarum $\left(10^{10} \mathrm{CFU} / \mathrm{g}\right)$ in a bunker silo on a concrete floor. The bacteria were produced by the Institute of Microbiology, Xinjiang Academy of Agricultural Sciences (Xinjiang, China). With the same method whole maize plants were chopped to make silage. Both silages were sealed for a month, and then fed to cows as TMR feed.

\section{Animals and feeding procedures}

Animal care, all procedures and experimental protocols in the study were approved by the Tian Shan Animal Husbandry Bio-engineering Co., Ltd., Chang Ji, Xinjiang (China). Fifty pregnant Holstein dairy cows before calving were grouped according to the parity and expected calving dates and assigned randomly to control $(\mathrm{BW}=715.7 \pm 16.3 \mathrm{~kg})$ and experimental $(\mathrm{BW}=710.9 \pm 15.5 \mathrm{~kg})$ groups. Animals from the latter group received diet where $10 \%$ of maize silage was replaced with ETP on dry matter (DM) basis. The control diet did not contain any tomato pomace. Animals during dry period were fed a dry cow diet (Table 1), and the corresponding diets of early lactating cows were replaced after calving. After late perinatal period, 15 cows with similar calving times were selected from each group and fed a lactating cow diet (Table 1) in order to make determinations of intake, digestibility, milk production, blood antioxidant status and immune index.

The animals were kept in individual concrete tie-stall with permanent free access to drinking water and mineral blocks throughout the whole feeding trial (KangTeEr Feed Technology Co, Ltd., Yueyang, China). TMR diets were supplied two times a day at 8:00 and 15:00. Feed refusals (approximately $10 \%$ per day) were collected and weighed before feeding at 6:00.

\section{Sampling and chemical analysis}

Silage composition. After 30 days of fermentation, both silage samples were collected. Subsamples $(50 \mathrm{~g})$ were macerated with $150 \mathrm{ml}$ of distilled water and stored in a refrigerator at $4{ }^{\circ} \mathrm{C}$ for $12 \mathrm{~h}$. The extract was filtered with no. 5 filter paper (Whatman, Little Chalfont, UK). The silage $\mathrm{pH}$ was determined with a $\mathrm{pH}$ meter (F-50 HORIBA, Kyoto, Japan). Lactic acid and volatile fatty acids were determined by high-performance liquid chromatography (HPLC) with Kromasil $\mathrm{C}_{18}$ column (length, $150 \mathrm{~mm}$; i.d., $4.6 \mathrm{~mm}$; temp., $20^{\circ} \mathrm{C}$; flow rate, $1 \mathrm{ml} / \mathrm{min}$; Kromasil, Bohus, Sweden).

Feed intake, apparent total tract digestibility. After calving, the TMR amounts offered and refused from 15 cows during the 7-day collection period were measured. At that time, daily DMI for each cow was calculated. Representative samples of experimental TMR, and individual refusals were taken immediately before the morning feeding during the 7-day collection period. At sampling day, at 5:00, 9:00, 13:00 and 17:00 faeces $(100 \mathrm{~g})$ were collected from each cow, and the 7-day faecal samples of the same cow of the same weight were 
Table 1. Ingredient and nutrient compositions of total mixed ration fed to cows during dry and lactating periods

\begin{tabular}{|c|c|c|c|c|}
\hline \multirow{3}{*}{ Indices } & \multicolumn{4}{|c|}{ Experimental diet } \\
\hline & \multicolumn{2}{|l|}{ dry period } & \multicolumn{2}{|l|}{ lactating period } \\
\hline & control & experimental & control & experimental \\
\hline \multicolumn{5}{|c|}{ Ingredient composition, \% dry matter (DM) } \\
\hline maize silage & 40 & 30 & 32 & 22 \\
\hline alfalfa hay & 18 & 18 & 24 & 24 \\
\hline wheat straw & 12 & 12 & - & - \\
\hline cottonseed & - & - & 4 & 4 \\
\hline tomato pomace silage & - & 10 & - & 10 \\
\hline concentrate $^{1}$ & 30 & 30 & 36 & 36 \\
\hline steam flaked maize & - & - & 4 & 4 \\
\hline \multicolumn{5}{|l|}{ Chemical composition } \\
\hline DM, \% as fed & 55.08 & 54.67 & 49.58 & 52.66 \\
\hline crude protein, \% DM & $12.3 \pm 0.32$ & $13.1 \pm 0.18$ & $15.3 \pm 0.38$ & $16.2 \pm 0.19$ \\
\hline neutral detergent fibre, \% DM & $42.6 \pm 1.35$ & $41.6 \pm 1.43$ & $33.3 \pm 0.72$ & $31.9 \pm 1.17$ \\
\hline ether extract, \% DM & $2.9 \pm 0.65$ & $3.0 \pm 0.41$ & $3.4 \pm 0.25$ & $4.6 \pm 0.12$ \\
\hline $\mathrm{NE}_{\mathrm{L}}{ }^{2}, \mathrm{Mcal} / \mathrm{kg}$ & $1.6 \pm 0.01$ & $1.6 \pm 0.01$ & $1.8 \pm 0.01$ & $1.8 \pm 0.01$ \\
\hline vitamin $\mathrm{A}, \mathrm{IU} / \mathrm{kg}$ & $4040 \pm 39.68$ & $9813 \pm 86.98$ & $4344 \pm 68.11$ & $10120 \pm 87.30$ \\
\hline vitamin $E^{3}, I U / k g$ & $34.2 \pm 2.20$ & $57.9 \pm 1.88$ & $33.3 \pm 0.76$ & $69.5 \pm 1.63$ \\
\hline $\mathrm{Ca}, \%$ & $0.6 \pm 0.02$ & $0.6 \pm 0.02$ & $0.7 \pm 0.03$ & $0.7 \pm 0.01$ \\
\hline $\mathrm{P}, \%$ & $0.3 \pm 0.00$ & $0.3 \pm 0.02$ & $0.5 \pm 0.02$ & $0.5 \pm 0.02$ \\
\hline $\mathrm{Cu}, \mathrm{mg} / \mathrm{kg}$ & $16.0 \pm 1.42$ & $16.0 \pm 1.18$ & $17.0 \pm 4.06$ & $15.6 \pm 2.23$ \\
\hline $\mathrm{Zn}, \mathrm{mg} / \mathrm{kg}$ & $45.6 \pm 0.78$ & $50.6 \pm 0.77$ & $53.2 \pm 058$ & $56.4 \pm 0.61$ \\
\hline $\mathrm{Mn}, \mathrm{mg} / \mathrm{kg}$ & $35.1 \pm 0.70$ & $36.2 \pm 0.18$ & $37.2 \pm 0.35$ & $32.8 \pm 0.18$ \\
\hline $\mathrm{Fe}, \mathrm{mg} / \mathrm{kg}$ & $527 \pm 3.67$ & $618 \pm 2.75$ & $516.4 \pm 2.87$ & $580 \pm 2.01$ \\
\hline $\mathrm{Se}^{4}, \mathrm{mg} / \mathrm{kg}$ & $0.2 \pm 0.10$ & $0.2 \pm 0.21$ & $0.3 \pm 0.04$ & $0.3 \pm 0.09$ \\
\hline
\end{tabular}

${ }^{1}$ soyabean meal, cotton meal, maize germ meal, concentrate contained per kg: mg: Cu 3 230, Zn 5 950, Mn 4 850, I 120, Se 150, Co 90, nicotinic

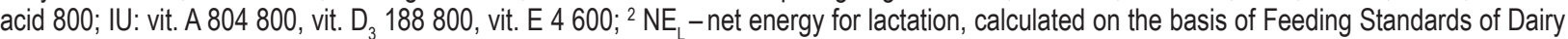
Cattle (Ministry of Agriculture of China MOA, 2004); ${ }^{3}$ chemical form(s) of vitamin E is a-tocopherol; ${ }^{4}$ chemical form(s) of Se is selenomethione

mixed and combined into a $150-\mathrm{g}$ sample. TMR and faecal samples were stored at $-20^{\circ} \mathrm{C}$ and analysed for acid-insoluble ash as an internal marker to calculate apparent digestibility.

Milk yield and composition. During 14 days after calving the cows were milked 3 times a day at 2:00, 7:00 and 14:00 using a bucket milker. Milk samples were collected from each lactating cow.

Blood metabolites, antioxidant status and immunity. Blood samples were drawn from the caudal veins into sampling tubes before calving, at calving, 7 and 14 days after calving. Before and after calving blood samples were taken at 7:00 before feeding, but sampling at calving day (day 0) was performed immediately after calving. Within an hour from drawing, blood samples were centrifuged at $3000 \mathrm{~g}$ for $10 \mathrm{~min}$ at $25^{\circ} \mathrm{C}$. The sera were kept at $-30{ }^{\circ} \mathrm{C}$ until analysis.

\section{Measurement and analysis}

Silage and diet. DMI was determined as the difference between offered and refused DM. Samples of both diets were collected daily and the composition of the samples was analysed chemically for DM, crude protein $(\mathrm{CP})$ and ether extract (EE) according to AOAC (2000) procedures, and $\alpha$-neutral detergent fibre (NDFom), $\alpha$-acid detergent fibre (ADFom) by the method of Van Soest et al. (1991). Heatstable $\alpha$-amylase was used in the NDF assay, and the results are presented exclusive of residual ash. Estimation of calcium $(\mathrm{Ca})$ and phosphorus $(\mathrm{P})$ were analysed by O-Cresolphthalein-Complexone, Vanadium-Ammonium Molybdate Colorimetric method, using a visible spectrophotometer (Shanghai Jinghua Technology Instruments Co, Ltd., Shanghai China). Copper $(\mathrm{Cu})$, zinc $(\mathrm{Zn})$, manganese $(\mathrm{Mn})$, iron $(\mathrm{Fe})$ were determined by GB/T 13885-2017. Selenium (Se) was determined by GB/T 13883-2008 and using TAS 990 Intec Roma model (Beijing Persee General Instrument Co. Ltd, Beijing, China) of atomic absorption spectrophotometer. The net energy for lactation was calculated based on Ministry of Agriculture (MOA) of China. After saponification and extraction with petroleum ether $\alpha$-tocopherol and retinol were separated by reverse phase chromatography method (LC98; Beijing WENFEN Analytical Instrument Development Co., Ltd, Beijing, China), of which the content is determined by external standard method with a reversed-phase $\mathrm{C}_{18}$ column (Spherisorb ODS2: length, $250 \mathrm{~mm}$; i.d., $4.6 \mathrm{~mm}$; particle size, $5 \mu \mathrm{m}$; Waters, Milford, MA, USA) maintained at $35^{\circ} \mathrm{C}$. The mobile phase was composed of methyl methanol and water in a ratio of 98:2. The flow rate was $1 \mathrm{ml} / \mathrm{min}$. 
Detection wavelengths for $\alpha$-tocopherol and retinol were $280 \mathrm{~nm}$ and $325 \mathrm{~nm}$, respectively. The injection volume was $20 \mu \mathrm{l}$ (applied in GB 5413.9-2010).

Vitamin $\mathrm{C}$ was estimated by the 2,6-dichloroindophenol method according to GB 5009.86-2016. Quantification of VC was performed by HPLC with a reversed-phase $\mathrm{C}_{18}$ column (Spherisorb ODS2: length, $250 \mathrm{~mm}$; i.d., $4.6 \mathrm{~mm}$; particle size, $5 \mu \mathrm{m}$; Waters, Milford, MA, USA) maintained at $25^{\circ} \mathrm{C}$. The mobile phase was composed of A: $6.8 \mathrm{~g}$ of potassium dihydrogen phosphate and $0.91 \mathrm{~g} 16$ alkyl trimethylammonium bromide, dissolved in water and made to $11 \mathrm{(pH}$ maintained at 2.5-2.8 with phosphoric acid); B: $100 \%$ methanol; A and B in a ratio of $98: 2$. The flow rate was $0.7 \mathrm{ml} / \mathrm{min}$. Detection wavelength was $245 \mathrm{~nm}$. The injection volume was $20 \mu 1$.

$\beta$-carotene content was quantitatively determined by external standard method in GB 5009.832016. After saponification with absolute ethanol and potassium hydroxide solution $(75: 25)$, carotene was released into a free state. After extraction with petroleum ether to determine a small volume, $\beta$-carotene was separated by reversed-phase chromatography with a reversed-phase $\mathrm{C}_{18}$ column (Spherisorb ODS2: length, $250 \mathrm{~mm}$; i.d., $4.6 \mathrm{~mm}$; particle size, $5 \mu \mathrm{m}$; Waters, Milford, MA, USA) maintained at $35^{\circ} \mathrm{C}$. The mobile phase was composed of chloroform, acetonitrile and methanol in a ratio of 3:12:85. The flow rate was $2 \mathrm{ml} / \mathrm{min}$. Detection wavelength was $450 \mathrm{~nm}$. The injection volume was $20 \mu \mathrm{l}$.

Digestibility. Samples of faeces and diet were dried in a forced-air oven at $60{ }^{\circ} \mathrm{C}$ and ground in order to go through a 1-mm screen. Compositions of samples of diets and faeces were evaluated through the analysis of acid insoluble ash (AIA) using a modified $3 \mathrm{~N} \mathrm{HCl}$ method of Keulen and Young (1977).

Digestibility values were calculated as follows:

AIA dry matter digestibility $=$

$100-100 \times\left(\frac{\% \text { marker in diet }}{\% \text { marker in faeces }}\right) \times\left(\frac{\% \text { nutrient in faeces }}{\% \text { nutrient in diet }}\right)$

Milk composition. Milk components (protein, lactose and fat) were determined with an automatic milk analyser (Bulgarian Lactoscan MCC 50, Milkotronic Ltd, Nova Zagora, Bulgaria). Determination of vitamin content in milk was applied in GB 5413.92010. The HPLC system consisted of a reversedphase $\mathrm{C}_{18}$ column (Spherisorb ODS2: length, $250 \mathrm{~mm}$; i.d., $4.6 \mathrm{~mm}$; particle size, $5 \mu \mathrm{m}$; Waters, Milford, MA, USA), a mobile phase based on methanol and use of rotary evaporation at temperature not exceeding
$40{ }^{\circ} \mathrm{C}$ to condense the volume of petroleum ether extract to $\sim 2 \mathrm{ml}$. The condensed petroleum ether extract was transfered to a $10-\mathrm{ml}$ brown volumetric flask, dry with nitrogen and dilute to the mark with methanol. Flow rate was $2 \mathrm{ml} / \mathrm{min}$, integrated at $325 \mathrm{~nm}$ (for VA) and $294 \mathrm{~nm}$ (for VE).

Blood analysis. Concentrations of glucose (Glu), total cholesterol (TC), thyroglobulin (TG), urea, low density lipoprotein cholesterol (LDL-C) and high-density lipoprotein cholesterol (HDL-C) in serum samples were determined using an Automatic Clinical Chemistry Analyser (Sysmex XN-1000B3, Sysmex Corporation Ltd, Kobe, Japan). Concentration of malondialdehyde (MDA, $\mu \mathrm{mol} / \mathrm{l})$ was determined by thiobarbituric acid (TBA) reaction, following the protocol of Uchiyama and Mihara (1978) using a UNICO 7200 visible spectrophotometer (UNICO Instrument Co., Ltd., Shanghai, China). The total serum antioxidant capacity (T-AOC) was determined by the ferric reducing ability of the serum assay (Benzie and Strain, 1996), using a spectrophotometer (Specord 210 Plus, Analytik, Jena, Germany). Superoxide dismutase (SOD) activity in the erythrocyte lysate was measured using the RANSOD kit (Randox Laboritories Ltd, Crumlin, County Antrim, UK) and an automatic biochemical spectrophotometrical analyser Alizé (Lisabio, Poully en Auxois, France). Glutathione peroxidase (GSH-Px) activity was determined through the kinetic method (Paglia and Valentine, 1967) using the RANSEL kit (Randox Laboritories Ltd, Crumlin, County Antrim, UK) and the same spectrophotometrical analyser. The concentrations of IgG, IgA and IgM in the blood samples were determined using single radial immunodiffusion using DG5033A Microplate Reader (Nanjing Huadong Electronics Group Medical Equipment Co., Ltd, Nanjing, China). The assays were conducted using the assay kits (Najiang Jiancheng Institute of Bioengineering, Nanjing, China).

California mastitis test (CMT). At calving day, twelve cows selected from each group had determined the prevalence of mastitis by the rapid, accurate, cowside field test recommended by the American Public Health Association. The CMT reagent reacts with DNA of epithelial and inflammatory cells present in the milk sample. CMT results were read immediately and were scored for each quarter depending on the thickness and amount of the gel formed. CMT scores of ' 0 ' and trace $( \pm)$ were taken as negative or normal, whereas CMT scores of + (weak positive),++ distinct positive) and +++ (strong positive) were considered as indicators of subclinical mastitis. 


\section{Data analysis}

Data were expressed as mean \pm standard error (SE) for all measurements performed on cows of each group. Statistical differences between the groups of feed intake, digestibility, feed composition, blood parameters were subjected to statistical analysis as one-way analysis of variance using the general linear model procedure of SPSS (IBM SPSS Statistics for Windows, Version 21.0., IBM Corp., Armonk, NY, USA). Duncan's multiple range test was used to separate means when the dietary experimental effect was significant. The MIXED procedure of SPSS was used to analyse the repeated measures data including antioxidant parameters and immunoglobulins. The statistical model included fixed effects of treatment, time and treatment by time with cow nested in the treatment as the random effect. Statistical differences were declared at $P \leq 0.01, P \leq 0.05$.

\section{Results}

\section{Silage quality}

Both silages (Table 2) were characterised by similar $\mathrm{pH}$ but total acid content was higher in ETP. None of them contained butyric acid. ETP contained more protein and ether extract than maize silage. Also, the content of analysed vitamins was higher in ETP.

Table 2. Quality and composition of tomato and maize silages

\begin{tabular}{|c|c|c|}
\hline Indices & Tomato pomace silage & Maize silage \\
\hline$\overline{\mathrm{pH}}$ & 4.01 & 3.97 \\
\hline Lactic acid, \% & 1.68 & 1.03 \\
\hline Acetic acid, \% & 0.75 & 0.35 \\
\hline Propionic acid, \% & 0.54 & 0.19 \\
\hline Butyric acid, \% & ND & ND \\
\hline Total acid, \% & 2.97 & 1.57 \\
\hline Moisture content, \% & 81.79 & 70.99 \\
\hline \multicolumn{3}{|c|}{ Composition, $\%$ of dry matter } \\
\hline organic matter & 91.08 & 93.88 \\
\hline crude protein & 16.46 & 8.46 \\
\hline ether extract & 12.23 & 3.87 \\
\hline a-NDFom & 50.34 & 52.23 \\
\hline a-ADFom & 43.23 & 41.09 \\
\hline
\end{tabular}

Vitamins

retinol, IU/kg 23600

$\beta$-carotene, $\mathrm{mg} / \mathrm{kg} \quad 90$

vitamin $\mathrm{E}, \mathrm{IU} / \mathrm{kg} \quad 10$

vitamin $\mathrm{C}, \mathrm{mg} / 100 \mathrm{~g} \quad 151.32$

Sugars, $\%$

pectin 5.78

sucrose $\quad 9.98$

glucose $\quad 7.3$

fructose $\quad 3.96$

starch

$$
2.87
$$

\subsection{4}

4.1

ND

ND

ND

1.09

2.45

ND

34.11

ND - not detected; a-NDFom - ash-corrected neutral detergent fibre, a-ADFom - ash-corrected acid detergent fibre

\section{DMI and digestibility}

Feed intake is presented in Table 3. Average DMI values were $17.8 \pm 0.06$ and $18.1 \pm 0.15 \mathrm{~kg}$ for the control and experimental groups, respectively, and the values were significantly different between the groups $(P<0.05)$. Feeding experimental diet also significantly increased intake rate and the average intake rates were $98.6 \pm 0.91$ and $91.3 \pm 0.30 \%$ in the experimental and control groups, respectively $(P<0.05)$. Faeces amount was decreased $(P<0.05)$ in the experimental group in comparison to the control group. Digestibility of DM in the experimental group was significantly higher $(P<0.05)$ than in the control group.

Table 3. Feed intake and apparent nutrient digestibility of nutrients during after parturition

\begin{tabular}{llll}
\hline Indices & \multicolumn{1}{l}{$\begin{array}{l}\text { Control } \\
\text { group }\end{array}$} & $\begin{array}{l}\text { Experimental } \\
\text { group }\end{array}$ & $P$-value \\
\hline Feed intake, kg DM/day & $17.8 \pm 0.06$ & $18.1 \pm 0.15$ & 0.03 \\
Intake rate, \% & $91.3 \pm 0.30$ & $98.6 \pm 0.91$ & 0.00 \\
Faeces amount, kg DM/day & $5.4 \pm 0.02$ & $4.9 \pm 0.04$ & 0.00 \\
Apparent nutrient digestibility, \% & & \\
$\quad$ DM & $69.5 \pm 0.05$ & $72.8 \pm 0.03$ & 0.00 \\
$\quad$ crude protein & $77.7 \pm 4.53$ & $79.5 \pm 4.25$ & 0.35 \\
a-NDFom & $60.8 \pm 6.36$ & $63.9 \pm 5.02$ & 0.41 \\
\hline
\end{tabular}

a-NDFom - ash-corrected neutral detergent fibre; DM - dry matter

\section{Milk yield and milk composition}

The daily milk production in the control and experimental groups were $23.8 \pm 3.88$ and $25.3 \pm 3.55 \mathrm{~kg} /$ day, respectively; the difference between these values was not significant $(P>0.05)$ (Table 4). Milk composition did not differ between groups $(P>0.05)$, but vitamin $\mathrm{A}$, vitamin $\mathrm{E}$, and vitamin $\mathrm{C}$ concentrations were significantly higher in treatment group than in the control one $(P<0.05)$.

Table 4. Yield and composition of milk obtained from the early lactating Holstein cows fed tomato pomace silage

\begin{tabular}{lllc}
\hline Indices & \multicolumn{1}{l}{$\begin{array}{l}\text { Control } \\
\text { group }\end{array}$} & $\begin{array}{l}\text { Experimental } \\
\text { group }\end{array}$ & $P$-value \\
\hline Milk yield, kg/day & $23.8 \pm 3.88$ & $25.3 \pm 3.55$ & 0.53 \\
Milk composition, \% & & & \\
$\quad$ fat & $3.7 \pm 0.54$ & $3.6 \pm 0.42$ & 0.10 \\
$\quad$ protein & $3.0 \pm 0.07$ & $3.0 \pm 0.08$ & 0.80 \\
$\quad$ lactose & $4.5 \pm 0.08$ & $4.5 \pm 0.12$ & 0.91 \\
$\quad$ non-fat milk solid & $8.1 \pm 0.21$ & $8.1 \pm 0.19$ & 0.93 \\
Vitamin A, IU/kg & $0.8 \pm 0.20$ & $2.0 \pm 0.83$ & 0.04 \\
Vitamin E, mg/kg & $16.8 \pm 8.03$ & $39.0 \pm 2.61$ & 0.00 \\
Vitamin C, mg/100 g & $6.7 \pm 1.38$ & $17.5 \pm 1.10$ & 0.00
\end{tabular}




\section{Blood metabolites}

The results of serum biochemical analysis for both groups of cows are given in Table 5. Serum albumin (Alb) concentration in the experimental group was higher $(P<0.05)$ than in the control group before calving and higher concentration after calving in the experimental group, but differences were not significant. Significant differences were observed in the serum concentrations of TC and HDL-C to the control group before parturition. $\gamma$-glutamyl transpeptidase $(\gamma$-GTP) concentrations in the treatment group were significantly lower than in the control group during the post-parturition period $(P<0.05)$.

\section{Antioxidant parameters}

As shown in Figure 1, one week after calving, experimental group had higher T-AOC compared to control group $(P<0.05)$; (treatment $\times$ time interaction: $P=0.001)$. All the indicators of the antioxidant status of the cows from the start of the experiment showed no differences between the groups $(P>0.05)$. A significantly lower MDA concentration in the experimental group was recorded at calving $(P<0.01)$ and one week after calving $(P<0.05)$ in comparison to the control group. A significantly higher SOD activity was observed in the experimental group than in the control group

Table 5. Blood biochemistry of the animals fed control and experimental diet based on tomato pomace silage

\begin{tabular}{|c|c|c|c|c|c|c|}
\hline \multirow{3}{*}{ Indices } & \multicolumn{6}{|c|}{ Experimental diet } \\
\hline & \multicolumn{2}{|c|}{ before parturition } & \multirow{2}{*}{$P$-value } & \multicolumn{2}{|l|}{ after parturition } & \multirow{2}{*}{$P$-value } \\
\hline & control & experimental & & control & experimental & \\
\hline $\mathrm{TP}, \mathrm{g} / \mathrm{l}$ & $68.10 \pm 8.2$ & $67.62 \pm 5.9$ & 0.910 & $76.7 \pm 4.3$ & $72.90 \pm 2.8$ & 0.099 \\
\hline Alb, g/l & $31.03 \pm 2.8$ & $34.05 \pm 1.4$ & 0.037 & $32.13 \pm 1.2$ & $33.35 \pm 1.1$ & 0.092 \\
\hline Glu, mmol/l & $3.89 \pm 0.1$ & $3.89 \pm 1.2$ & 0.970 & $3.35 \pm 0.2$ & $3.40 \pm 0.2$ & 0.719 \\
\hline BUN, mmol/l & $3.64 \pm 0.7$ & $4.57 \pm 1.0$ & 0.075 & $5.57 \pm 0.5$ & $5.57 \pm 0.4$ & 0.990 \\
\hline $\mathrm{TC}, \mathrm{mmol} / \mathrm{l}$ & $1.90 \pm 0.3$ & $2.38 \pm 0.3$ & 0.020 & $3.53 \pm 0.9$ & $3.06 \pm 0.4$ & 0.265 \\
\hline HDL-C, mmol// & $1.12 \pm 0.1$ & $1.27 \pm 0.1$ & 0.015 & $1.97 \pm 0.4$ & $2.00 \pm 0.2$ & 0.870 \\
\hline LDL-C, mmol/l & $0.70 \pm 0.3$ & $0.82 \pm 0.4$ & 0.553 & $1.29 \pm 0.5$ & $1.01 \pm 0.2$ & 0.187 \\
\hline $\mathrm{TG}, \mathrm{mmol} / \mathrm{l}$ & $0.18 \pm 0.1$ & $0.22 \pm 0.0$ & 0.237 & $0.10 \pm 0.0$ & $0.12 \pm 0.0$ & 0.198 \\
\hline GOT, IU/I & $55.67 \pm 7.2$ & $60.50 \pm 9.6$ & 0.379 & $87.50 \pm 10.6$ & $87.17 \pm 17.8$ & 0.619 \\
\hline Y-GTP, U/I & $19.17 \pm 3.2$ & $20.83 \pm 3.5$ & 0.408 & $42.17 \pm 11.51$ & $21.33 \pm 2.6$ & 0.002 \\
\hline
\end{tabular}

TP - total protein, Alb - albumin, Glu - glucose, BUN - blood urine nitrogen, TC - total cholesterol, HDL-C - high-density lipoprotein cholesterol, LDL-C - low-density lipoprotein cholesterol, TG - thyroglobulin, GOT - glutamic oxaloacetic transaminase, $y$-GTP - v-glutamyl transpeptidase
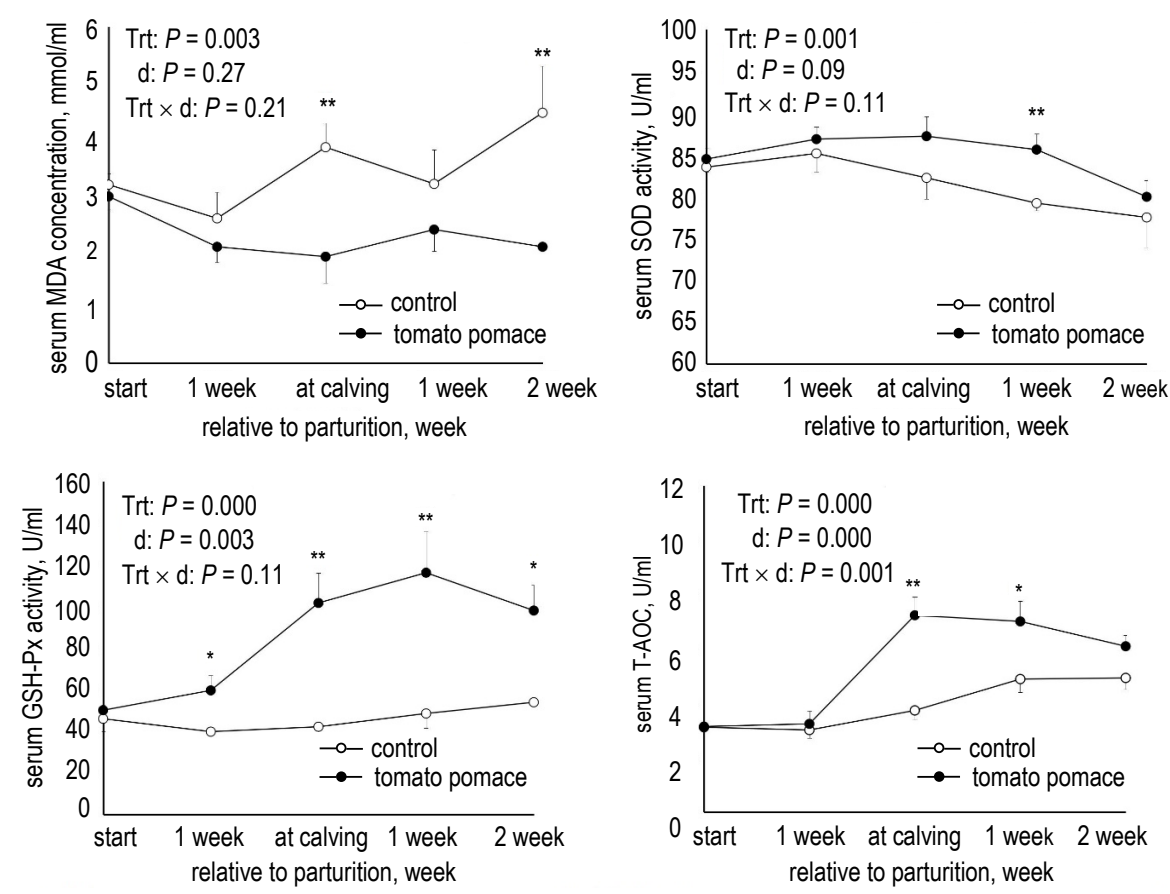

Figure 1. Glutatione peroxidase (GSH-Px), and superox dismulase (SOD) activities, malondialdehyde (MDA) concentration and total antioxidant capacity (T-AOC) of cows in the control $(n=8)$ and experimental group $(n=8)$ from the start of the experiment before calving, at calving and 16 days after calving. Standard errors of the mean are indicated by vertical bars at the time-point measurements. Statistic differences between the groups are indicated by ${ }^{*}$ and ${ }^{* *}$ at $P<0.05$ and $P<0.01$, respectively 
one week after parturition $(P<0.05)$. In the experimental group significantly high GSH-Px activity $(P<0.01)$ at calving (day 0$)$ and one week after calving $(P<0.01)$ was observed.

\section{Immune responses}

As shown in Figure 2, at calving animals from the experimental group had significantly higher IgA, $\operatorname{IgG}$ and $\operatorname{IgM}$ concentrations than those from the control group (treatment $\times$ time interaction: $P<0.05$,
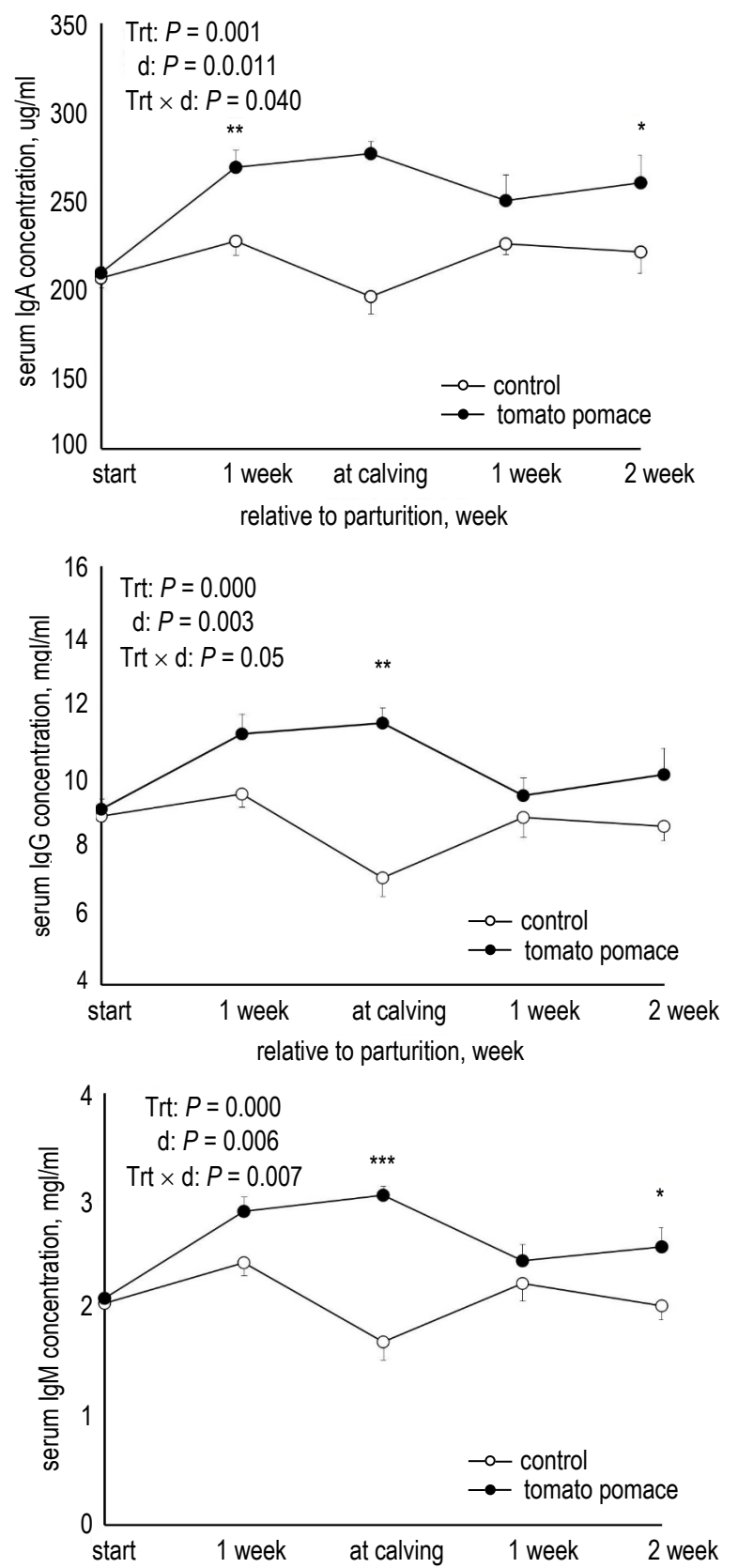

Figure 2. Serum concentration of $\lg A, \lg G$ and $\lg M$ of cows in the control $(n=8)$ and experimental group $(n=8)$ from the start of the experiment before calving, at calving, and 16 days after calving. Standard errors of the mean are indicated by the vertical bars at the time-point measurements. Statistic differences between the groups are indicated by ${ }^{*}$ and ${ }^{* *}$ at $P<0.05$ and $P<0.01$, respectively
$P<0.01, \quad P<0.01$, respectively). No significant differences in all immunoglobulins concentrations between the groups were observed from the start of the experiment $(P>0.05)$. The serum IgA and IgG concentrations in the treatment group recorded at calving $(P<0.05)$ were markedly higher than in the control one. Serum IgM concentrations recorded at calving and 1 week after calving also varied significantly between the groups of cows $(P<0.05$, $P<0.01$, respectively).

As shown in Table 6, according to CMT the prevalence of mastitis in the experimental and control group was 58.3 and $75 \%$, respectively $(P<0.05)$.

Table 6. Prevalence of mastitis in the milk samples of calving dairy cows by using California mastitis test (CMT)

\begin{tabular}{|c|c|c|c|c|c|c|c|c|}
\hline \multirow{2}{*}{ Groups } & \multirow{2}{*}{$\begin{array}{l}\text { Total no. } \\
\text { of samples, } \\
\text { head }\end{array}$} & Positive & $\frac{\text { tive }}{\text { of rate, }}$ & \multicolumn{2}{|l|}{ - Head } & \multicolumn{3}{|c|}{ Ranges, \% } \\
\hline & & he & & +++++ & + & +++ & ++ & + \\
\hline Control & 12 & 9 & 753 & 33 & 3 & 33.33 & 33.33 & 33.33 \\
\hline Experimental & 12 & 7 & 58.31 & 11 & 5 & 14.29 & 14.29 & 71.43 \\
\hline
\end{tabular}

\section{Discussion}

In the northern slopes of the Tianshan Mountains in Xinjiang (China) there are produced the largest amounts of processed tomatoes and there are developed the largest dairy industries. Tomato is an excellent source of many nutrients and secondary metabolites, namely vitamin $\mathrm{C}$, vitamin $\mathrm{E}, \beta$-carotene, lycopene and trace minerals that have health promoting activities (Giovanelli and Paradiso, 2002). In this study, we hypothesized that $10 \%$ replacement of maize silage by ETP may improve the antioxidant capacity and immunity of dairy cows during the pre-parturition and postparturition periods. Estimated net energy for lactation $\left(\mathrm{NE}_{\mathrm{L}}\right)$ in both treatment groups showed no limitation (according to the National Research Council (NRC, 2001)). $\mathrm{NE}_{\mathrm{L}}$ requirement for maintenance of dairy cows during dry off and early lactation periods derived from feeding trial were 1.44 and $1.71 \sim 1.76 \mathrm{Mcal} / \mathrm{kg}$, respectively. This indicated that there was no detrimental effect of energy deficiency. We have also shown that DMI and DM digestibility were not negatively affected when cows were fed diet with ETP addition, and that DMI significantly increased after parturition $(P<0.05)$. These findings are in line with the results of Abdollahzadeh and Pirmohammadi (2010), who observed that DMI was significantly increased when 
lactating cows were fed diets containing mixed ensiled tomato and apple pomace at concentrations of 15 or $30 \%$, respectively in comparison with that in the control animals. The increase in DMI can be partly explained by the high palatability of tomato pomace. We have observed that the ETP did not influence milk yield but significantly increased the concentrations of vitamin A, E and C in the milk. These observations agree with Loy et al. (2013), who observed that increasing the concentration of vitamin A in the diet can lead to an increase of vitamin A in the milk. Apart from this, the other milk compounds were not affected by the ETP addition.

Before parturition the concentration of TC and HDL-C were significantly higher in animals fed experimental diet than in those from control group $(P<0.05)$, whilst the triglycerides and LDL-C concentrations were unaffected. These findings are in partial agreement with the report of Selim et al. (2013), in which supplementation of heat-stressed broilers' diet with tomato puree had no significant effects on the triglyceride, total lipids, LDL-C, HDL-C and TC concentrations. In the several studies hypocholesterolemic effects of tomato derivatives and lycopene on humans and animals were noted. Increased HDL-C and decreased LDL-C, TC and serum total lipids were observed in rats supplemented with tomato juice for a 4-week period (Hassan and Edrees, 2004). Either combined or alone, supplementation with lycopene and vitamin $\mathrm{E}$ reduced serum cholesterol, while using a combination of these nutrients caused the greatest response (Sahin et al., 2006). Lycopene and hypocholesterolemic properties of tomato products may be related to a decrease in the synthesis of cholesterol by inhibiting the activities of 3-hydroxy-3methylglutaryl coenzyme A (HMG-CoA) reductase and acylcoenzyme A: cholesterol acyltransferase (ACAT) and the expression and modulation of LDL receptor (Palozza et al., 2012).

Activities of antioxidant enzymes, e.g., GSH-Px and SOD were increased while that of MDA decreased in cows during late pregnancy (Stowe and Herdt, 1992). In the present study it was found that a dietary supplementation of ETP partially alleviated the detrimental effect of antioxidant activity in transition dairy cows. Considerable amounts of antioxidant compounds including lycopene, vitamins $\mathrm{C}, \mathrm{E}, \mathrm{A}$ and $\beta$-carotene have been found in tomato derivatives (Tengerdy, 1989). Sahin et al. (2004) have shown that the concentrations of serum oxidative stress markers, such as MDA and homocysteine were decreased when the diet of heat-stressed Japanese quails concentrations of lycopene, vitamin $\mathrm{C}$ and vitamin $\mathrm{E}$ increased upon supplementation of pure lycopene. Supplementation of 2.5 and $5 \%$ tomato powder to broiler diet decreased MDA concentration in the liver, while increased concentrations of catalase, lycopene, SOD and GSH-Px in quails reared under heat stress conditions. However, more recently it was observed that in Holstein-Friesian calves receiving flax oil $(10 \mathrm{~g} /$ day $)$ with lyophilized apples $(25 \mathrm{~g})$ as natural product, increased T-AOC and GSH-Px levels in blood serum were observed (Śpitalniak-Bajerska et al., 2020). Thus, the consumption of tomato products can not only influence the tissue status of these microconstituents in the body, but also may maintain the vitamins levels through their antioxidant properties (Tyssandier et al., 2004).

In animals, vitamin $\mathrm{E}$ is an important biological catalyst, which can activate $\beta$-lymphocyte proliferation and participate in the synthesis of IgG and IgM antibodies (Tanaka et al., 1979). In several experiments it was shown that vitamin $\mathrm{E}$ can improve animal humoral and cellular immunities in experimental animals (Bendich et al., 1986; Reddy et al., 1987). In the present study we have found that IgA, IgM and IgG concentrations significantly increased in the experimantal group during calving, and these findings are similar to that reported by Hidiroglou et al. (1992, 1995), who showed that serum IgM and IgG concentrations were higher in cattle subjected to vitamin E supplementation than in those from the control group. These observations might be explained by the fact that the levels of vitamin A and E were higher when cows were fed diets with ETP before and after calving in comparison to those who did not receive such diet $(P<0.05)$. During perinatal period, the control animals were fed diet covering NRC requirements concerning the amounts of vitamin A and E. However, in cows from the experimental group the corresponding values were higher during dry and lactation period.

\section{Conclusions}

Supplementation of cow diet with $10 \%$ of ensiled tomato pomace (ETP) improved the dry matter (DM) intake and digestibility of peripartum dairy cows. It can also ensure vitamins A, E and $\mathrm{C}$ contents in milk, improve the antioxidant status and immune response during the peripartum period, and also reduce the prevalence of mastitis at calving day. It is suggested that partial replacement of whole crop maize silage with $10 \%$ of ETP, 
as a natural antioxidant feed source, improves the antioxidant status and immune responses of peripartum dairy cows. Therefore, the effect of different storage time on fermentation and aerobic stability of ETP as well as effects of mixed of tomato pomace and whole plant maize on silage fermentation quality and stability need to be studied in the future.

\section{Acknowledgements}

The author thanks the National Natural Science Foundation of China for their financial assistance (Grant No. 31472125). We further express our thanks to Xinjiang Agricultural University and all the staff of Xin Jiang Tianshan Animal Husbandry Bio-engineering Company for the use of their facilities and for their kind help when needed.

\section{References}

Abdollahzadeh F., Pirmohammadi R., 2010. Effect of feeding ensiled mixed tomato and apple pomace on performance of holstein dairy cows. Ital. J. Anim. Sci. 9, 212-216, https://doi. org/10.4081/ijas.2010.e41

Albanese D., Adiletta G., D'Acunto M., Cinquanta L., Di Matteo M., 2014. Tomato peel drying and carotenoids stability of the extracts. Int. J. Food Sci. Technol. 49, 2458-2463, https://doi.org/10.1111/ ijfs. 12602

AOAC International, 2000. Official Methods of Analysis of AOAC International. $17^{\text {th }}$ Edition. Gaithersburg, MD (USA)

Bendich A., Gabriel E., Machlin L.J., 1986. Dietary vitamin E requirement for optimum immune responses in the rat. J. Nutr. 116, 675-681, https://doi.org/ 10.1093/jn/116.4.675

Benzie I.F.F., Strain J.J., 1996. The ferric reducing ability of plasma (frap) as a measure of "antioxidant power": the frap assay. Anal. Biochem. 239, 70-76, https://doi.org/10.1006/abio.1996.0292

Chew B.P., 1993. Role of carotenoids in the immune response. J. Dairy Sci. 76, 2804-2811, https://doi.org/10.3168/jds.S00220302(93)77619-5

Chew B.P., Park J.S., 2004. Carotenoid action on the immune response. J. Nutr. 134, 257S-261S, https://doi.org/10.1093/jn/134.1.257S

Czauderna M., Białek M., Białek A., Śliwiński B., Brzóska F., 2020. Chemical form of dietary selenium affects the fatty acids profile and oxidative stability of muscles of broilers supplemented with lycopene and oils. Eur. J. Lipid Sci. Technol. 122, 1900132, https://doi.org/10.1002/ejtt.201900132

Ebeid H., Gawad R.M.A., Mahmoud A.E.M., 2015. Influence of ration containing tomato pomace silage on performance of lactating buffaloes and milk quality. Asian-Austral. J. Anim. Sci. 10, 14-24, https://doi.org/10.3923/ajava.2015.14.24

Fondevila M., Guada J.A., Gasa J., Castrillo C., 1994. Tomato pomace as a protein supplement for growing lambs. Small Ruminant Res. 13, 117-126, https://doi.org/10.1016/0921-4488(94)90086-8

Fuentes E., Forero-Doria O., Carrasco G., Marican A., Santos L.S., Alarcon M., Palomo I., 2013. Effect of tomato industrial processing on phenolic profile and antiplatelet activity. Molecules 18, 11526-11536, https://doi.org/10.3390/ molecules 180911526
GB 5413.9-2010: Determination of Vitamins A, D, E in Foods for Infants and Young Children. National Health and Family Planning Commission of the People's Republic of China. Beijing (China)

GB 5009.86-2016: Determination of ascorbic acid in food. National Health and Family Planning Commission of the People's Republic of China. Beijing (China)

GB/T 13883-2008: Determination of selenium in feeds. National Health and Family Planning Commission of the People's Republic of China. Beijing (China)

GB/T 13885-2017: Determination of the contents of calcium, copper, iron, magnesium, manganese, potassium, sodium and zinc in feeds-Method using atomic absorption spectrometry. National Health and Family Planning Commission of the People's Republic of China. Beijing (China)

GB/T 5009.83-2016: Determination of $\beta$-carotene in foods for infants and young children, milk and milk products. National Health and Family Planning Commission of the People's Republic of China. Beijing (China)

Giovanelli G., Paradiso A., 2002. Stability of dried and intermediate moisture tomato pulp during storage. J. Agric. Food Chem. 50, 7277-7281, https://doi.org/10.1021/jf025595r

Goff J.P., 2006. Major advances in our understanding of nutritional influences on bovine health. J. Dairy Sci. 89, 1292-1301, https://doi.org/10.3168/jds.s0022-0302(06)72197-x

Hassan H.A., Edrees G.M., 2004. Therapeutic effect of lycopenerich tomato juice on cardiac disorder in rats fed on fried food in oxidized frying oil. Egypt. J. Hosp. Med. 14, 115-126

Hidiroglou M., Batra T.R., Ivan M., Markham F., 1995. Effects of supplemental vitamins $E$ and $C$ on the immune responses of calves. J. Dairy Sci. 78, 1578-1583, https://doi.org/ 10.3168/ jds.S0022-0302(95)76781-9

Hidiroglou N., Cave N., Atwall A.S., Farnworth E.R., Mcdowell L.R., 1992. Comparative vitamin $E$ requirements and metabolism in livestock. Ann. Rech. Vet. 23, 337-359, https:// hal.archives-ouvertes.fr/file/index/docid/902095/filename/ hal-00902095.pdf

Hogan J.S., Smith K.L., Weiss W.P., Todhunter D.A., Schockey W.L., 1990. Relationships among vitamin E, selenium, and bovine blood neutrophils. J. Dairy Sci. 73, 2372-2378, https://doi. org/10.3168/jds.S0022-0302(90)78920-5

Jin L., Yan S., Shi B., Bao H., Gong J., Guo X. et al., 2014. Effects of vitamin $A$ on the milk performance, antioxidant functions and immune functions of dairy cows. Anim. Feed Sci. Technol. 192, 15-23, https://doi.org/10.1016/j.anifeedsci.2014.03.003

Keulen J.V., Young B.A., 1977. Evaluation of acid-insoluble ash as a natural marker in ruminant digestibility studies. J. Anim. Sci. 44, 282-287, https://doi.org/10.2527/jas1977.442282x

Loy S.L., Kns S., Hamid Jan J.M., 2013. Increase in maternal adiposity and poor lipid profile is associated with oxidative stress markers during pregnancy. Prev. Med. 57, S41-S44, https:// doi.org/10.1016/j.ypmed.2012.11.021

Mdel V., Camara M., Torija M.E., 2006. Chemical characterization of tomato pomace. J. Sci. Food Agric. 86, 1232-1236, https:// doi.org/10.1002/jsfa.2474

MOA (Ministry of Agriculture, China), 2004. Feeding Standard of Dairy Cattle (NY/T 34-2004). Beijing (China)

NRC (National Research Council), 2001. Nutrient Requirements of Dairy Cattle. $7^{\text {th }}$ Revised Edition. The National Academies Press. Washington, DC (USA), https://doi.org/10.17226/9825

Omar H.A.A., Abdel-Magid S.S., 2015. Incorporation of dried tomato pomace in growing sheep rations. Glob. Vet. 14, 1-16, http:// doi.org/10.5829/idosi.gv.2015.14.01.9256 
Paglia D.E., Valentine W.N., 1967. Studies on the quantitative and qualitative characterization of erythrocyte glutathione peroxidase. J. Lab. Clin. Med. 70, 158-169, https://doi.org/10 .1080/15389588.2012.749466

Palozza P., Catalano A., Simone R.E., Mele M.C., Cittadini A., 2012. Effect of lycopene and tomato products on cholesterol metabolism. Ann. Nutr. Metab. 61, 126-134, https://doi. org/10.1159/000342077

Rahbarpur A., Taghizadeh A., Mehmannavaz Y., 2013. Determination of nutritive value of tomato pomace using in vitro gas production technique. Online J. Anim. Feed Res. 3, 20-22, http://ojafr.ir/main/attachments/article/92/Online\%20J.\%20 Anim.\%20Feed\%20Res.,\%203(1)\%2020-22;\%202013.pdf

Reddy P.G., Momll J.L., Minocha H., Stevenson J.S., 1987. Vitamin $E$ is immunostimulatory in calves. J. Dairy Sci. 70, 993-999, https://doi.org/10.3168/jds.S0022-0302(87)80104-2

Rozbicka-Wieczorek A.J., Szarpak E., Brzóska F., Śliwiński B., Kowalczyk J., Czauderna M., 2012. Dietary lycopenes, selenium compounds and fish oil affect the profile of fatty acids and oxidative stress in chicken breast muscle. J. Anim. Feed Sci. 21, 705-724, https://doi.org/10.22358/jafs/66143/2012

Sahin K., Ozercan R., Onderci M. et al., 2004. Lycopene supplementation prevents the development of spontaneous smooth muscle tumors of the oviduct in Japanese quail. Nutr. Cancer. 50, 181-189, https://doi.org/10.1207/ s15327914nc5002_8

Sahin N., Sahin K., Onderci M., Karatepe M., Smith M. O., Kucuk O., 2006. Effects of dietary lycopene and vitamin $\mathrm{E}$ on egg prodcution, antioxidant status and cholesterol levels in Japanese quail. Asian-Australas. J. Anim. Sci. 19, 224-230, https://doi. org/10.5713/ajas.2006.224

Selim T., Berndtsson R., Persson M., 2013. Simulation of soil water and salinity distribution under surface drip irrigation. Irrig. Drain. 62, 352-362, https://doi.org/10.1002/ird.1739

So S., Cherdthong A., Uriyapongson S., 2019. Potential use of tomato pomace as ruminants diet - A review. Biosci. Res. $16,1538-1548$
Spears J.W., 2000. Micronutrients and immune function in cattle. Proc. Nutr. Soc. 59, 587-594, https://doi.org/10.1017/ S0029665100000835

Stowe H.D., Herdt T.H., 1992. Clinical assessment of selenium status of livestock. J. Anim. Sci. 70, 3928-3933, https://doi. org/10.2527/1992.70123928x

Sundrum A., 2015. Metabolic disorders in the transition period indicate that the dairy cows to adapt is overstressed. Animals 5, 978-1020, https://doi.org/10.3390/ani5040395

Śpitalniak-Bajerska K., Szumny A., Pogoda-Sewerniak K., Kupczyński R., 2020. Effects of n-3 fatty acids on growth, antioxidant status, and immunity of preweaned dairy calves. J. Dairy Sci. 103, 2864-2876, https://doi.org/10.3168/jds.2019-17001

Tanaka J., Fujiwara H., Torisu M., 1979. Vitamin E and immune response. I. Enhancement of helper $\mathrm{T}$ cell activity by dietary supplementation of vitamin $\mathrm{E}$ in mice. Immunology 38, 727-734, https://www.ncbi.nlm.nih.gov/pmc/articles/ PMC1457854/pdf/immunology00261-0074.pdf

Tengerdy R.P., 1989. Vitamin E, immune response, and disease resistance. Ann. NY Acad. Sci. 570, 335-344, https://doi. org/10.1111/j.1749-6632.1989.tb14932.x

Tyssandier V., Feillet-Coudray C., Caris-Veyrat C. et al., 2004. Effect of tomato product consumption on the plasma status of antioxidant microconstituents and on the plasma total antioxidant capacity in healthy subjects. J. Am. Coll. Nutr. 23, 148-156, https://doi.org/10.1080/07315724.2004.10719355

Uchiyama M., Mihara M., 1978. Determination of malonaldehyde precursor in tissues by thiobarbituric acid test. Anal. Biochem. 86, 271-278, https://doi.org/10.1016/0003-2697(78)90342-1

Van Soest P.J., Robertson J.B., Lewis B.A., 1991. Methods for dietary fiber, neutral detergent fiber and non-starch polysaccharides in relation to animal nutrition. J. Dairy Sci. 74, 3583-3597, https://doi.org/10.3168/jds.S0022-0302(91)78551-2

Weiss W.P., Frobose D.L., Koch M.E., 1997. Wettomato pomace ensiled with corn plants for dairy cows. J. Dairy Sci. 8, 2896-2900, https://doi.org/10.3168/jds.S0022-0302(97)76254-4

Xinjiang Statistical Yearbook (in Chinese), 2017. Statistical Bureau of Xinjiang Uygur Autonomous Region. Statistics Press. Beijing (China) 